\title{
38. PALEOMAGNETIC STUDY OF DEEP-SEA SEDIMENTS FROM THE CAGAYAN RIDGE IN THE SULU SEA: RESULTS OF LEG 1241
}

\author{
Vindell Hsu, ${ }^{2}$ Hidetoshi Shibuya,${ }^{3}$ and Dean L. Merrill ${ }^{4}$
}

\begin{abstract}
Discrete samples from ODP Sites 769 and 771 , located on the Cagayan Ridge in the Sulu Sea, are subjected to paleomagnetic study. The general results indicate that the coarse-grained and chaotic tuff and lapillistone below the soft sediment cover are not suitable for paleomagnetic study and that sediment layers cored by XCB and RCB techniques produce poor data due to rotary disturbance. The top $220 \mathrm{~m}$ of the sediments penetrated by APC cores at Site 769, however, produced very high-quality data. The polarities of the discrete samples agree very well with the magnetic reversal sequences that we established for Site 769 during the shipboard paleomagnetic study using archive halves of APC cores. Hole 769A includes the Brunhes-Matuyama Epoch boundary and Hole 769B contains 36 reversals including most of the reversals after the boundary between Chrons C4a and C5 about 8.92 Ma. Rapid change in both declinations and inclinations occurs at about $135 \mathrm{~m}$ below seafloor. This change can be shown to be due to normal faulting rather than tectonic movements. The resulting lack of convincing evidence for rotation or north-south migration for the Cagayan Ridge site is remarkable because the nearby Philippine Islands and the Celebes Sea to the southeast have had counter-clockwise rotation in their tectonic evolution history. The result suggests that the spreading of the Sulu Sea as a back-arc basin did not cause rotation or north-south migration of the Cagayan Ridge and that the tectonic activities within the Philippine Mobile Belt have been decoupled from the Cagayan Ridge since middle Miocene time.
\end{abstract}

\section{INTRODUCTION}

The major scientific objective of ODP Leg 124 was to investigate the origin of the many marginal seas in the western Pacific Ocean. Preliminary results from drilling in the Sulu and the Celebes Seas reveal that these marginal basins may have very different origins (Leg 124 Shipboard Scientific Party, 1989). During Leg 124, shipboard pass-through paleomagnetic measurement of archive halves of APC cores has produced high-quality data that establish long magnetic reversal sequences contributing to dating of the sediment columns in both seas (Rangin, Silver, von Breymann, 1990). In this paper, we report the detailed shore-based measurement of oriented discrete samples taken from Sites 769 and 771 and discuss the implications of the results on the tectonics of the Cagayan Ridge and the Sulu Sea, where they are located.

The Sulu Sea lies between Borneo and the Philippine Archipelago in the western Pacific. An approximately $600-\mathrm{km}$ long northeast-trending island chain formed by the Palawan Islands separates it from the South China Sea to the northwest 8(Fig. 1). To the southeast, the Sulu Ridge separates it from the Celebes Sea. The subduction along the Sulu Trench is not active, judging from the seismicity data (National Earthquake Information Center, 1987). The Cagayan Ridge is a distinctive northeast-trending bathymetric high that subdivides the Sulu Sea into the shallower $(2000 \mathrm{~m})$ northwest Sulu Basin and the deeper southeast Sulu Basin (maximum $5500 \mathrm{~m}$ ).

The southeast Sulu Basin has a typical oceanic crust (Rangin, Silver, von Breymann, et al., 1990) and has been interpreted as

\footnotetext{
${ }^{1}$ Silver, E. A., Rangin, C., von Breymann, M. T., et al., 1991. Proc. ODP, Sci. Results, 124: College Station, TX (Ocean Drilling Program).

${ }^{2}$ Department of Geology and Geophysics, Louisiana State University, Baton Rouge, LA 70803-4101, U.S.A.

${ }^{3}$ Department of Earth Sciences, College of Integrated Art and Science, University of Osaka Prefecture, Sakai 591, Japan.

${ }^{4}$ Department of Oceanography, Texas A\&M University, College Station, TX 77843, U.S.A.
}

either a result of back-arc spreading (Hamilton, 1979) or as a trapped piece of oceanic crust that was previously a portion of a larger continuous ocean basin that includes the present Sulu, Celebes, and Banda Seas (Lee and McCabe, 1986). The northwest Sulu Basin is considerably shallower than the southeast Sulu Basin and may be underlain by a volcanic arc. Together they represent an island arc system related to subduction of the north Palawan block beneath the Cagayan block (Leg 124 Shipboard Scientific Party, 1989).

Leg 124 drilled at three sites within the Sulu Sea with Site 768 located in central southeast Sulu Basin and Sites 769 and 771 on the Cagayan Ridge (Fig. 1). The paleontological data at the three sites give an age of early middle Miocene for bottom sediments for both the southeast Sulu Basin and the Cagayan Ridge. Drilling results indicate that the Cagayan Ridge is probably a volcanic arc formed by pyroclastics covered by a relatively thin sediment cover ( $279 \mathrm{~m}$ at Site 769 and $234 \mathrm{~m}$ at Site 771). The age of the oldest sediments at Sites 769 and 771 suggests that the volcanic activity along the Cagayan Ridge ceased in early middle Miocene (about $18 \mathrm{Ma}$ ), when the Sulu Sea started to form.

\section{PALEOMAGNETIC SAMPLES}

Discrete paleomagnetic samples were taken on board the JOIDES Resolution during Leg 124. These samples consist of 6- $\mathrm{cm}^{3}$ cubes for sediments and 1-in. diameter, 1-in.-long minicores for basement basalt or lapillistone. All samples are oriented relative to the uphole vertical direction. Samples were taken from all cores and average about two samples per $1.5-\mathrm{m}$ section. For the tuff and lapillistone below the sediments, one sample per core was taken.

The discrete samples were measured by a cryogenic rock magnetometer and treated with stepwise AF or thermal demagnetizations. In general, both demagnetizations produce comparable results and individual samples have behaved well during demagnetization (Fig. 2) with well-defined primary components revealed after AF demagnetization of about 20 $\mathrm{mT}$ or thermal demagnetization of about $300^{\circ} \mathrm{C}$. The final 


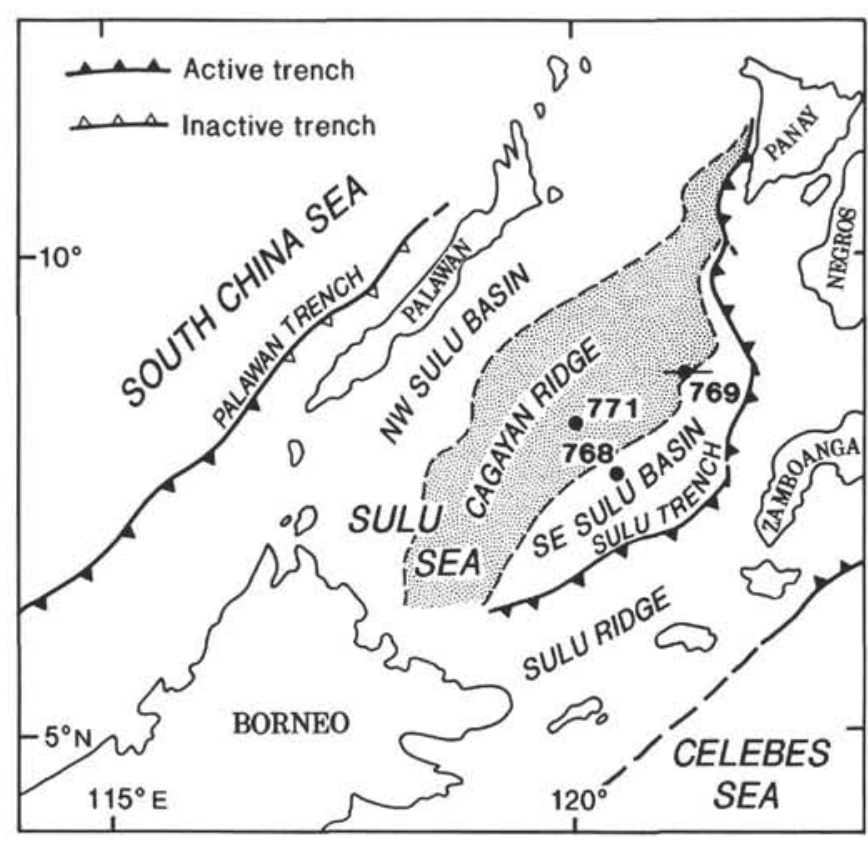

Figure 1. The Sulu Sea and the Cagayan Ridge with locations of Sites 769,771 , and 768. See Rangin, Silver, and von Breymann, et al. (1990) for detailed bathymetry. The short E-W line over Site 769 is the track of the seismic reflection line shown in Figure 11.

primary component directions are determined with the PCA (principal component analysis) technique (Krichvink, 1980).

It is important to identify the major magnetic signal carrier for any paleomagnetic study. The unaltered sediments from the Cagayan Ridge are likely to have magnetite as the major magnetic mineral, and detrital remanent magnetization (DRM) should be the main mechanism for the remanent magnetization. We have conducted an isothermal remanent magnetization (IRM) experiment to verify this. Seven samples representing the major lithologic units at Site 769 were treated with stepwise increasing magnetic fields from 0 to $1.2 \mathrm{~T}$ and are then stepwise thermal demagnetized up to $680^{\circ} \mathrm{C}$ (Fig. 3). The rapid increase in magnetization and attainment of saturation at about $0.3 \mathrm{~T}$ indicate that magnetite is the major magnetic mineral in all the samples. The linear decrease and sharp drop in magnetization at $580^{\circ} \mathrm{C}$ upon thermal demagnetization again verify the conclusion.

\section{TUFF AND LAPILLISTONE}

Below the sediment cover at both Sites 769 and 771, the rocks are described as massive, coarse-grained, unstratified tuff and structureless lapillistone with andesitic to basaltic composition (Rangin, Silver, von Breymann et al., 1990). At Site 771 the tuff below 234 mbsf is also capped and interbedded with basaltic lava flows. As the lithology may suggest, these chaotic pyroclastics proved not to be suitable for paleomagnetic studies after discrete samples are measured. Individual lapillistone samples are relatively strongly magnetized but show scattered directions during demagnetization (Fig. 2D). Many samples crumpled during thermal treatment. The overall paleomagnetic result of the pyroclastics for Holes $769 \mathrm{C}$ and 771A are shown in Figures 4 and 5, respectively. For both sites, the scatter in declinations and inclinations results from the chaotic nature of the lapillistone and the rotary disturbance due to RCB coring. The inclinations show great dispersion and no polarity intervals could be resolved. A few basalt samples from Site 771A show good behavior during demagnetization, and reasonable inclination values (Figs. 2C and 5).

\section{SEDIMENTS}

The sediments covering the Cagayan Ridge were cored continuously at Site 769 , and only the lower $90 \mathrm{~m}$ were so cored at Site 771 . Hole $769 \mathrm{~A}$ penetrated the top $67 \mathrm{~m}$ and Hole 769B penetrated the entire $279 \mathrm{~m}$ of sediments. The 24 relatively undisturbed APC cores from Hole 769B covering the top $220 \mathrm{~m}$ of the sediment column allowed us to produce a long (about $9 \mathrm{~m} . \mathrm{y}$.) record of the geomagnetic field at this site.

The paleomagnetic results of 60 discrete sediment samples from Hole 771A are shown in Figure 5. Because RCBs were used, the sediments were very much disturbed. Inclinations show highly scattered values and no polarity intervals could be determined.

At Hole 769A, the sediments were very magnetic and behaved well during AF demagnetization. The declinations and inclinations of 93 samples are plotted against depth in Figure 6 . The declinations have been corrected for core orientation using data from the multishot orientation tool so that the declinations are relative to the true north. An offset of declination for Core $124-769 \mathrm{~A}-2 \mathrm{H}$ is due to bad core orientation data. The clear direction change including swing of declination by $180^{\circ}$ and change of inclination sign at $62.4 \mathrm{mbsf}$ marks the reversal between the Brunhes and Matuyama Epochs indicating that Hole $769 \mathrm{~A}$ covers a little more than $0.73 \mathrm{~m} . \mathrm{y}$.

A stratigraphic plot of 436 discrete sample directions against depth for Hole 769B is shown in Figure 7. Below 220.8 mbsf the sediments show dispersed directions due to XCB coring. Samples of APC cores within the top $220.8 \mathrm{~m}$ show clear normal and reversed intervals. Because of the low latitude $\left(8.8^{\circ} \mathrm{N}\right)$ of Site 769 , the polarities are best indicated by the declination data. Both declination and inclination data also show intervals of dispersed values and these intervals can be correlated to the slump beds identified in the core descriptions by the shipboard sedimentologist.

We compared the polarities of the discrete samples to the magnetic reversal sequence that we established for Site 769 during shipboard paleomagnetic measurement of the archive halves of the APC cores (Rangin, Silver, von Breymann, 1990). Because the shipboard pass-through measurement was done at $10-\mathrm{cm}$ intervals, we could assign reversal depths with accuracy of $0.1 \mathrm{~m}$. This reversal sequence is shown in Figure 7 as the polarity column. The correlation between the shipboard pass-through measurement result and the shore-based discrete sample result is very good except for those samples within slump beds.

The magnetic reversal sequence shown in Figure 7 includes 36 reversals for the most recent seven magnetic polarity chrons. The oldest reversal is designated the boundary between Chrons $\mathrm{C} 4 \mathrm{a}$ and $\mathrm{C} 5$, which is about $8.92 \mathrm{Ma}$. Most of the younger reversals can be also correlated to the standard magnetic polarity sequence (Berggren et al., 1985) with little uncertainty. For a detailed listing of depths of reversals, the readers are referred to (Rangin, Silver, von Breymann, et al., 1990)

The magnetic reversal sequence shown in Figure 7 is compared to the nannofossil zones in Figure 8. The NN zones were determined during ship-board studies (Rangin, Silver, von Breymann, et al., 1990), and the ages followed Berggren et al. (1985). The correlation in Figure 8 shows good agreement with magnetic reversal depths following the nannofossil zones closely for the entire upper $220 \mathrm{~m}$. This result suggests that the sedimentation for the top $220 \mathrm{~m}$ sediments at Site 769 was continuous (except for a few disturbed slump beds) and that the assignment of magnetic Chrons was reasonable. The 

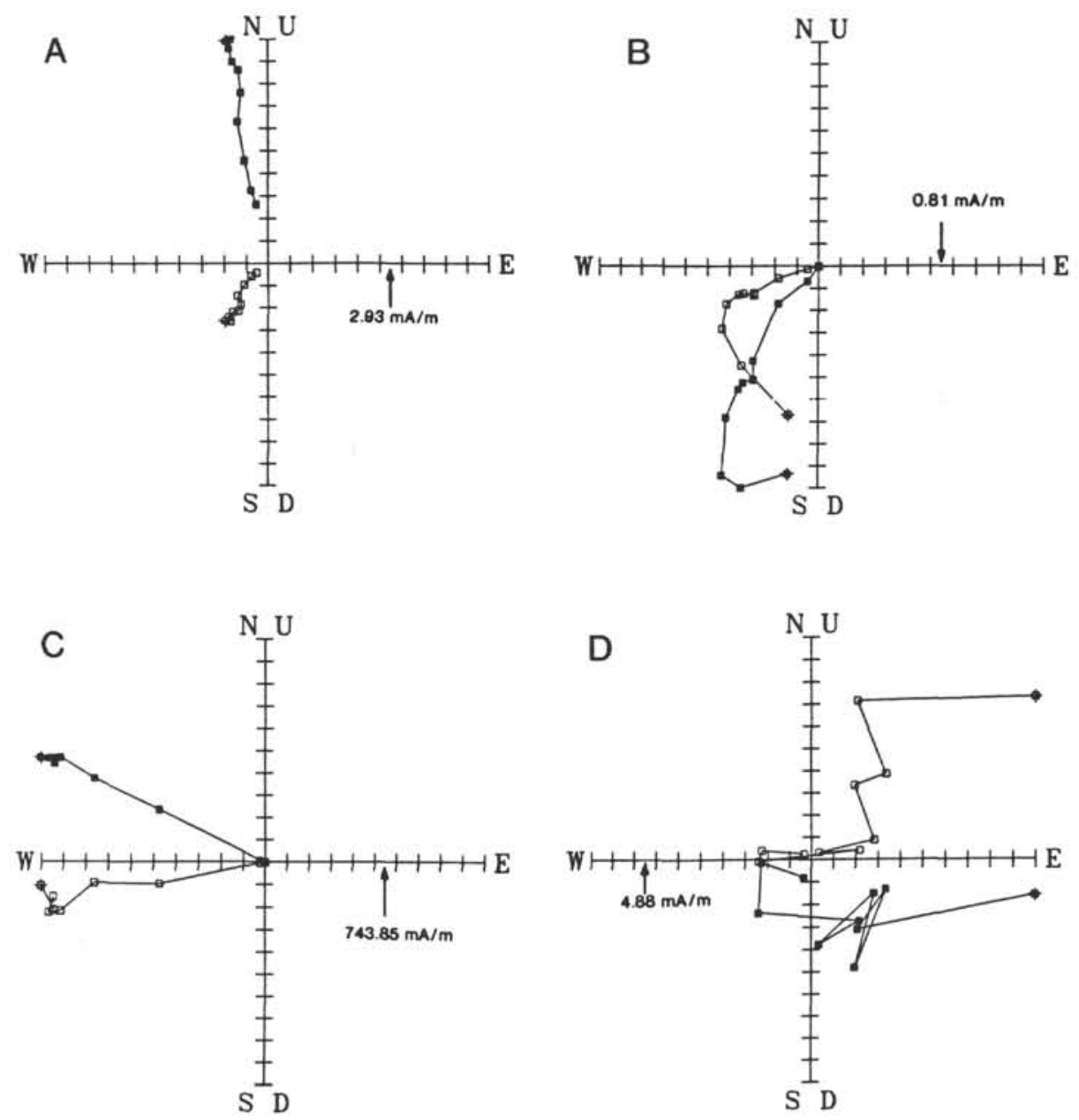

Figure 2. Demagnetization vector diagrams of four samples from Hole 769B. A. Sample 124-769B-7H-6, 25.0-27.0 cm showing AF demagnetization up to $45 \mathrm{mT}$. B. Sample 124-769B$22 \mathrm{H}-3,125.0-127.0 \mathrm{~cm}$ showing thermal demagnetization up to $600^{\circ} \mathrm{C}$. C. A basalt sample 124-771A-16R-1, 31.0-34.0 cm showing thermal demagnetization up to $700^{\circ} \mathrm{C}$. D. A lapillistone Sample $124-769 \mathrm{C}-11 \mathrm{R}-3,75.0-77.0 \mathrm{~cm}$ showing thermal demagnetization up to $700^{\circ} \mathrm{C}$. Filled squares show vertical (V-E) projection and open squares show horizontal (N-E) projection.

correlation, however, is not perfect, which can be due to many factors including uncertainties in absolute age assignments for the magnetic reversals and nannofossil zone boundaries. The uncertainties for NN zone boundary depths may also contribute, to some degree, to the disagreement.

\section{DIRECTIONAL CHANGES}

In addition to establishing magnetic reversal sequences for dating, paleomagnetic data from long ODP cores offer clues to the lithospheric plate movement. We have averaged the directions of discrete samples within each of the 24 APC cores from Hole 769B. Before averaging, data for samples within slump beds (Fig. 7) were eliminated. The declinations were then corrected for APC core penetration rotation. This error is due to rotation of the sediments by the core barrel when the APC core penetrates the sediments. The amount of rotation is largest at top and none at the bottom of each core (e.g., see Core $124-769 \mathrm{~B}-5 \mathrm{H}$ and $-6 \mathrm{H}$ in Fig. 7). The rotation can be up to $40^{\circ}$ and we corrected the declinations at different levels by an amount determined by linear interpolation of declinations at the top and bottom of a core. Finally, we inverted the directions for all identified reversed sections so that the averaging was done for assumed normal polarity.
We used the standard Fisher technique (Fisher, 1953) to obtain the averaged direction and the statistical parameters $\mathrm{K}$ (precision parameter) and $\alpha 95$ (the $95 \%$ confidence level). The result is listed in Table 1 and plotted in Figures 9 and 10for inclinations and declinations, respectively. The averaged inclination is $10.3^{\circ}$ at the top (average of $124-769 \mathrm{~B}-1 \mathrm{H},-2 \mathrm{H}$, and $-3 \mathrm{H}$ ) and $-7.9^{\circ}$ (average of $124-769 \mathrm{~B}-22 \mathrm{H},-23 \mathrm{H}$, and $-24 \mathrm{H}$ ) near the bottom of the APC cores. Figure 9 shows a clear change of inclination from negative to positive values near Core $124-769 \mathrm{~B}-16 \mathrm{H}$. This inclination change confirms what we have observed during the shipboard study. This interesting result suggests either that the Cagayan Ridge formed in the Southern Hemisphere and subsequently moved to the present northern latitude or that sediments below Core 124-769B-16H were tilted after they were deposited. This will be discussed in the following section.

The average declinations (Fig. 9) also show a systematic change. The off-trend average declinations for cores 124$769 \mathrm{~B}-1 \mathrm{H},-12 \mathrm{H},-13 \mathrm{H},-14 \mathrm{H},-15 \mathrm{H},-19 \mathrm{H}$, and $-21 \mathrm{H}$ are apparently due to bad core orientation data. The cores below $124-769 \mathrm{~B}-15 \mathrm{H}$ show consistently higher values than those above it. The average declination for $124-769 \mathrm{~B}-22 \mathrm{H},-23 \mathrm{H}$, and $-24 \mathrm{H}$ is $9.7^{\circ}$. This result could suggest a clockwise rotation of the Cagayan Ridge during the past $9 \mathrm{~m} . \mathrm{y}$. 


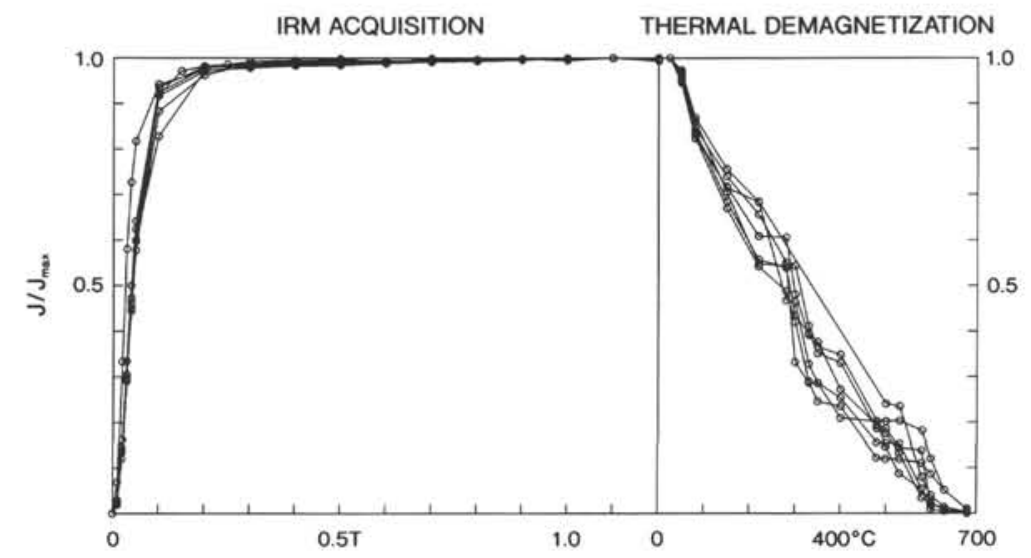

Figure 3. Results of IRM acquisition followed by thermal demagnetization of seven samples representing major sediment lithology types in Hole 769B. The sample numbers are $124-769 \mathrm{~B}-1 \mathrm{H}-2,74-76 \mathrm{~cm}, 124-769 \mathrm{~B}-4 \mathrm{H}-5,75-77 \mathrm{~cm}$, 124-769B-14H-1, 104-106 cm, 124-769B-20H-5, 25-27 cm, 124-769B-23H-6, $25-27 \mathrm{~cm}, 124-769 \mathrm{~B}-29 \mathrm{X}-1,135-137 \mathrm{~cm}$, and 124-769B-30X-2, 100-102 cm.

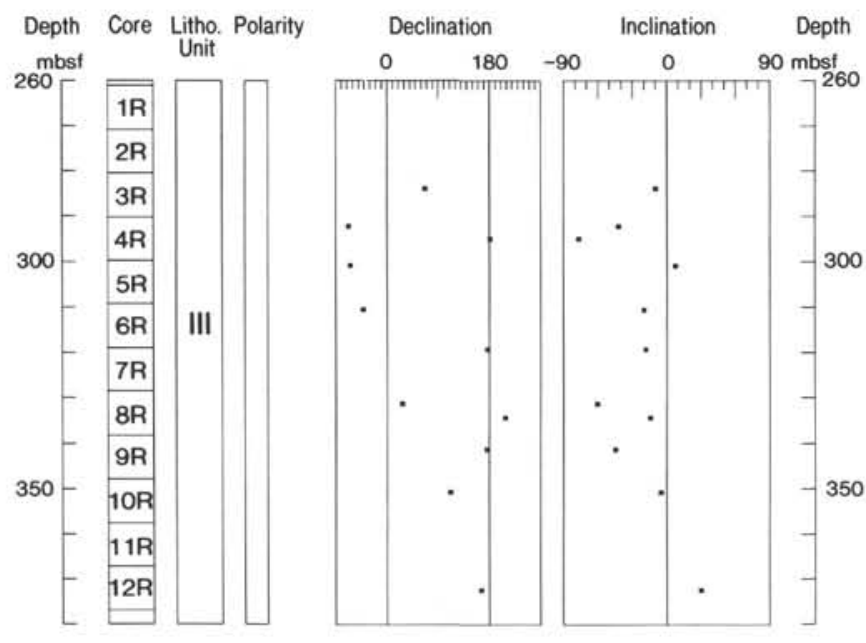

Figure 4. Stratigraphic plot of paleomagnetic directions for samples from Hole $769 \mathrm{C}$. No polarity intervals could be identified.

\section{DISCUSSION}

The synchronism of sudden declination and inclination change at about 135 mbsf suggests that they are related. Consider the total inclination difference (between the top and bottom of the APC cores) and assume that the change occurred over the time period when the sediments recovered in Cores $124-769 \mathrm{~B}-14 \mathrm{H}$ to $-17 \mathrm{H}$ were deposited (other cores above and below these four cores do not show continuous change), the inclination change would suggest a northward movement of $1140 \mathrm{~km}$ over a 2.1-m.y. period. This high northward migration rate of $543 \mathrm{~km} / \mathrm{m}$.y. is faster than any presently known plate motion. We, therefore, rule out the possibility of migration of Site 769 from the Southern Hemisphere to the present north latitude. The other possibility is that the direction change is due to tilting of the sediments occurred at about 4.2 Ma. Measurement of orientations of sedimentary layer bedding planes at Core 124$769 \mathrm{~B}-20 \mathrm{H}$ to $-23 \mathrm{H}$. shows an averaged dipping direction of $227^{\circ}$ and a dipping angle of $21^{\circ}$ (Rangin, Silver, von Breymann et al., 1990). Assuming Site 769 has not moved, a

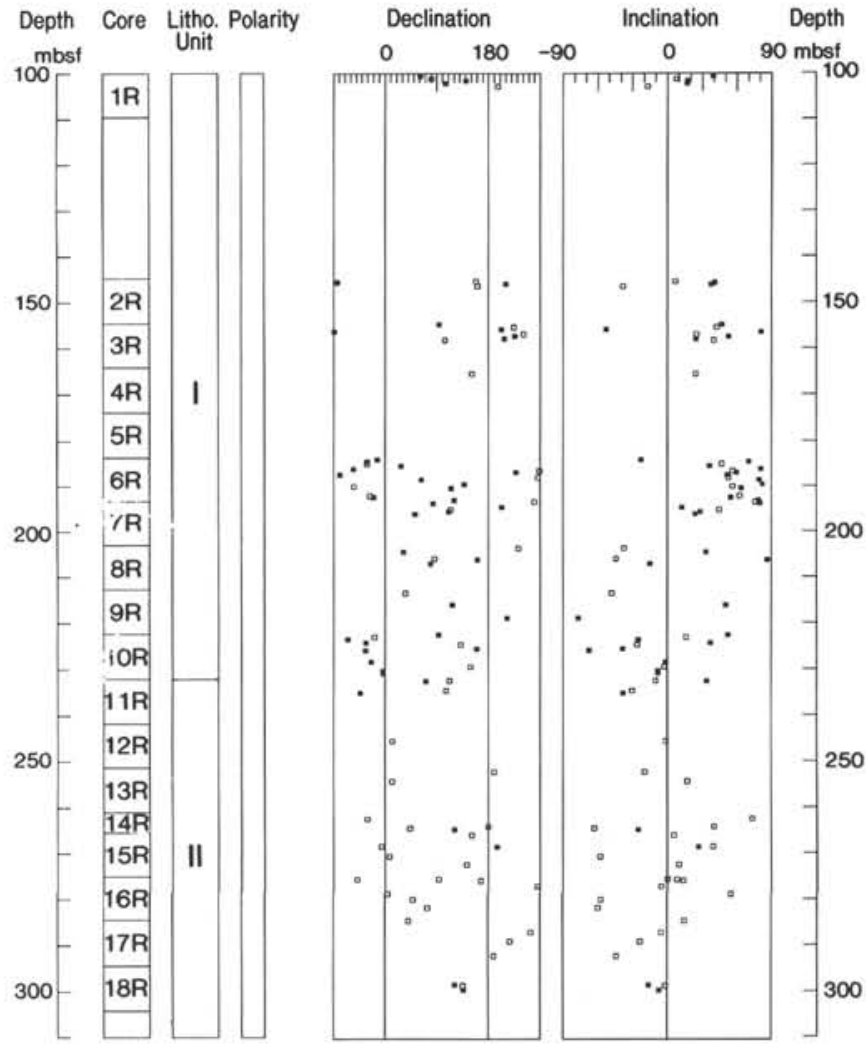

Figure 5. Stratigraphic plot of paleomagnetic directions for samples from Hole 771A. Open squares and filled squares show $\mathrm{AF}$ and thermal demagnetization results, respectively.

dipole geomagnetic field would predict a declination of $0^{\circ}$ and an inclination of $17.2^{\circ}$. The measured southwest tilting of the sediments would cause the declination to rotate $2.6^{\circ}$ clockwise and the inclination to decrease by $14.8^{\circ}$. This calculation is consistent with the observed directional change near core $124-769 \mathrm{~B}-15 \mathrm{H}$. The study of a seismic reflection line crossing Site 769B (Fig. 11) shows that Site 769 is located on the southeast flank of a volcano edifice and that abundant normal faults occur within both the sediments 


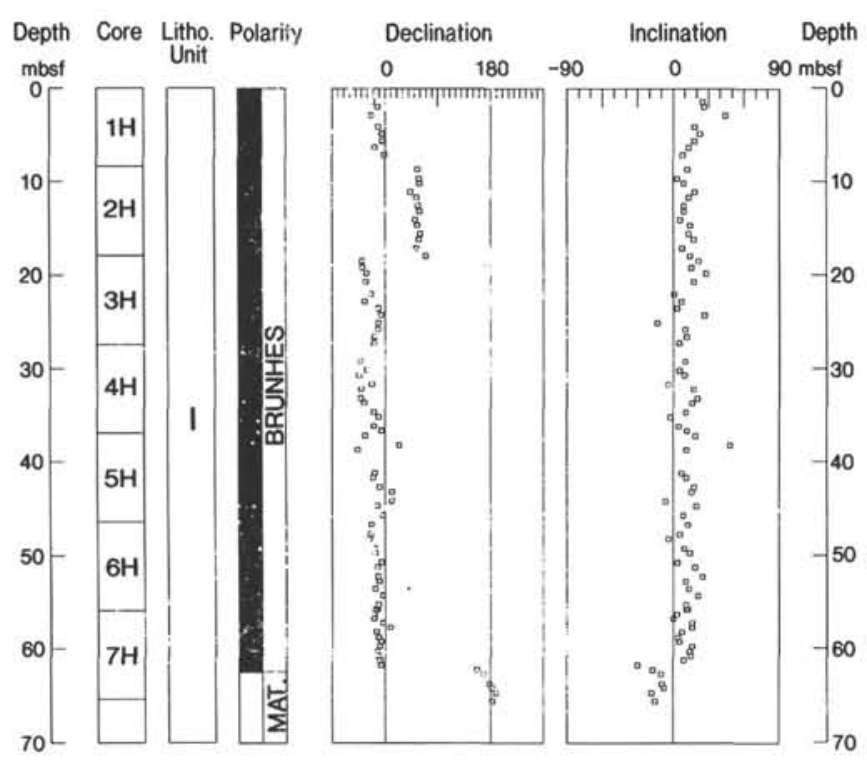

Figure 6. Stratigraphic plot of paleomagnetic directions for samples from Hole 769A with corresponding polarity intervals. All samples are AF demagnetized.

and the underlying pyroclastics. We conclude that the change in direction observed in Hole 769B is caused by tilting of the sediments due to normal faulting instead of northward migration and clockwise rotation of the Cagayan Ridge.

One interesting consideration is whether the tilting affected only a small section of the sediments or involved also the pyroclastics below the sediments. It is observed that sediment bedding planes were tilted in the low APC cores. The inclinations of the sediments below 220 mbsf cored by XCB are dominantly negative (Fig. 7). The tuff and Lapillistone cored at Hole $769 \mathrm{C}$ also show similar negative inclinations (Fig. 4), We think that these observations indicate that the normal faulting event about 4.2 Ma tilted both the sediments and the underlying pyroclastics.

The above analysis of Hole 769B discrete sample paleomagnetic directions suggests that the Cagayan Ridge did not have significant rotation or north-south migration since its volcanic activity ceased in early middle Miocene time. This statement is especially true for the past $4.2 \mathrm{~m}$.y. because the top $135 \mathrm{~m}$ of sediments have basically dipole predicted magnetic direction (Fig. 9 and 10). The period before $4.2 \mathrm{Ma}$ is less certain because the sediments were tilted. But the direction deviation could be largely accounted for by the tilting due to normal faulting.

This result is unique because the nearby Philippine Islands and the Celebes Sea to the southeast have undergone significant rotation. Fuller et al. (1983) showed that many parts of the Philippine islands have had $20^{\circ}$ of counterclockwise rotation since middle Miocene time. The discrete sample paleomagnetic result of the Celebes Sea Sites also suggests a $60^{\circ}$ counterclockwise rotation for the Celebes Sea since the $\mathrm{Pa}$ leocene time (Shibuya et al., this volume). The lack of evidence for rotation of the Cagayan Ridge suggests that it is decoupled from these two regions. The same bottom sediment age for the Cagayan Ridge and the Sulu Sea also suggests that the formation of the Sulu Sea as a back arc basin did not cause the Cagayan ridge to migrate or rotate.

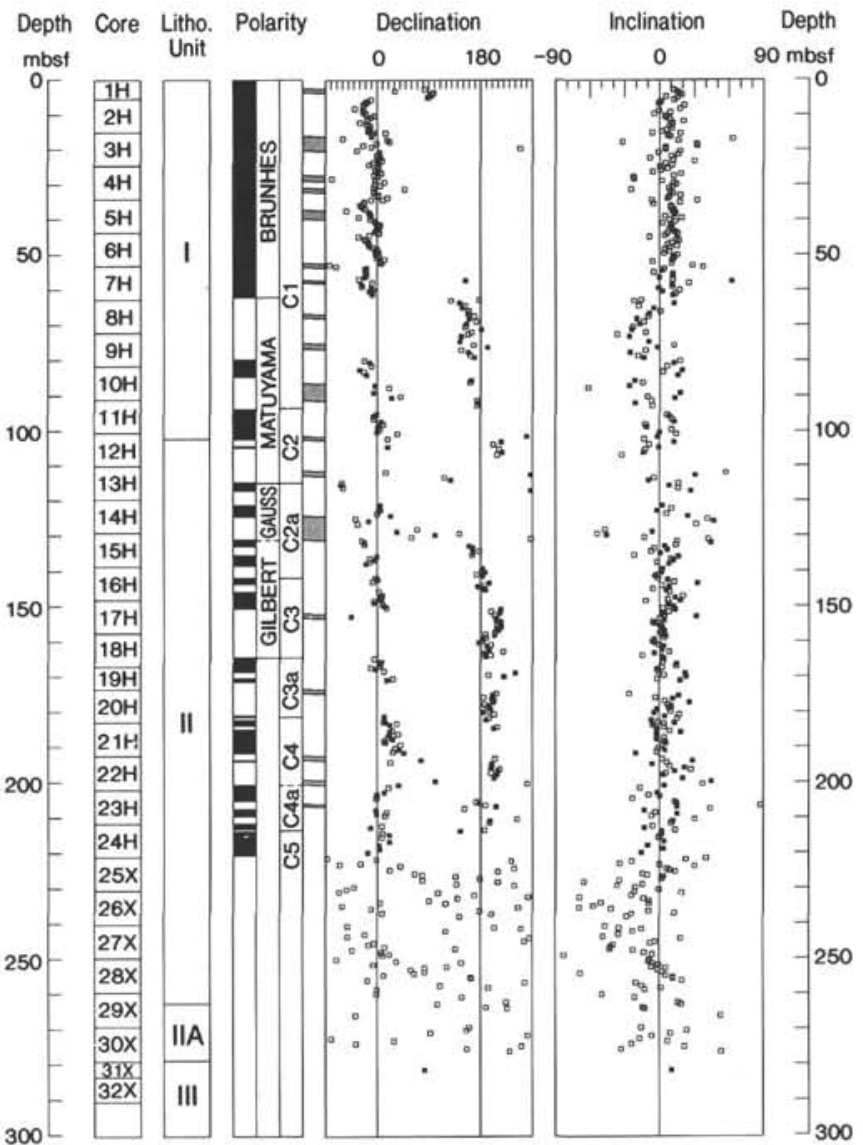

Figure 7. Stratigraphic plot of discrete sample paleomagnetic directions from Hole 769B. Symbols are the same as in Figure 5. Polarity intervals and magnetic chrons assignment are shown as the polarity column. Shaded regions between polarity and declination columns are slump bed intervals. Lithology units are described by Rangin, Silver, von Breymann, et al., (1990).

\section{CONCLUSIONS}

From the foregoing discussions we conclude the following:

1. The discrete samples from Sites 769 and 771 produced reliable paleomagnetic results for only the sections cored by the APC. Sediments recovered by XCB or RCB produced poor data due to rotary disturbances. The lapillistone and tuff consisting of coarse-grained material also proved unsuitable for paleomagnetic studies.

2. The top $220 \mathrm{~m}$ of sediments penetrated by the APC cores in Hole 769B produced a long reversal sequence that extends back to the boundary of Chrons C4a and C5 (about $8.9 \mathrm{Ma}$ ). Almost all the polarity intervals are positively identified except a few that are masked by slump beds.

3. A sudden declination and inclination change occurs at about $135 \mathrm{mbsf}$ at Hole 769B. The change is best interpreted to be due to normal faulting instead of tectonic movements of the Cagayan Ridge.

4. The lack of evidence for north-south migration and rotation of the Cagayan Ridge after its volcanic activity ceased in early middle Miocene time is unique because the Philippine Islands and the Celebes Sea were found to have counterclockwise rotations. These results suggest that the Cagayan Ridge was not rotated or migrated latitudinally and that the Philip- 
pine Islands have probably been decoupled from the Cagayan Ridge since early middle Miocene time.

\section{ACKNOWLEDGMENTS}

The authors wish to thank ODP for supporting this research by supplying samples. All support and scientific crewscontributed to the success of Leg 124. Shore-based measurement of discrete samples at LSU is supported by a grant from the JOI U.S. Science Support Program to V. H.

\section{REFERENCES}

Berggren, W. A., Kent, D. V., Flynn, J. J., and Van Couvering, J. A., 1985. Cenozoic geochronology. Geol. Soc. Am. Bull., 96:1407-1418. Fisher, R. A., 1953. Dispersion on a sphere. Proc. R. Soc. London A, 217:295-305.

Fuller, M., McCabe, R., Williams, I. S., Almasco, J., Encina, R. Y., Zanoria, A. S., and Wolfe, J. A., 1983. Paleomagnetism of Luzon. In Hayes, D. E. (Ed.), The Tectonic and Geological Evolution of Southeast Asia Seas and Islands. AGU Geophys. Monogr. Ser. 23:9-84.
Hamilton, W., 1979. Tectonics of the Indonesian region. Geol. Surv. Prof. Paper U.S., 1078.

Krichvink, J. L., 1980. The least square lines and planes and the analysis of paleomagnetic data. Geophys. J. R. Astron. Soc., 62:699-710.

Lee, C. S., and McCabe, R., 1986. The Banda Celebes Sulu Basins: a trapped piece of Cretaceous Eocene oceanic crust? Nature, 322:51-54.

Leg 124 Shipboard Scientific Party. 1989. Origins of marginal basins. Nature, 338:380-381.

National Earthquake Information Center, 1987. Global distribution of seismicity, 1977-1986 (map). Denver (U.S. Geol. Survey).

Rangin, C., Silver, E. A., von Breymann, M. T., et al., 1990. Proc. ODP, Init. Repts., 124: College Station, TX (Ocean Drilling Program).

Date of initial receipt: 4 June 1990

Date of acceptance: 7 January 1991

Ms 124B-167 


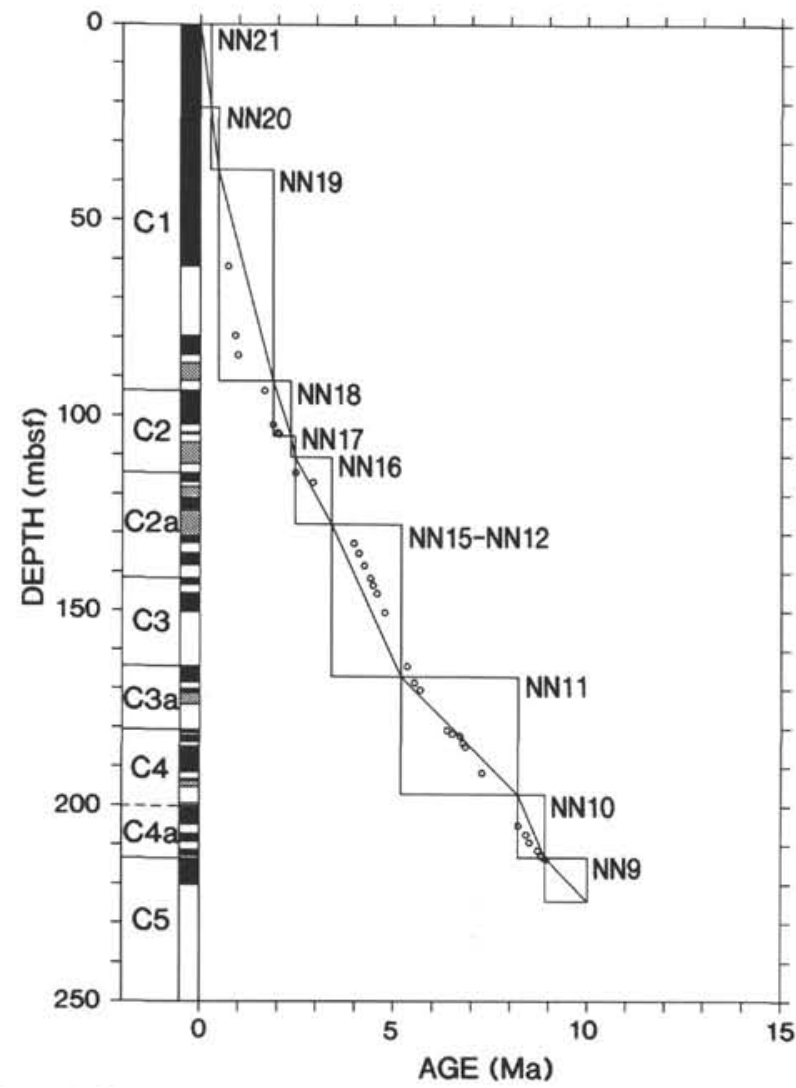

Figure 8. Correlation of magnetic reversal boundaries and the nannofossil zones. Magnetic chrons are shown along with the depth axis and ages are shown on the horizontal axis. Nannofossil zones were determined during shipboard studies (Rangin, Silver, von Breymann, 1990).

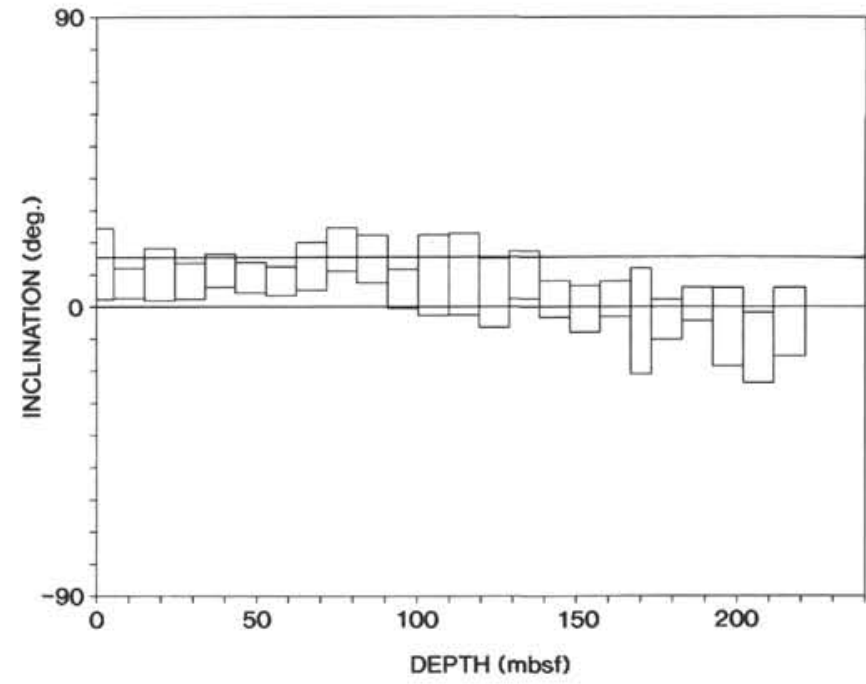

Figure 9. Average inclinations of the APC cores $(124-769 \mathrm{~B}-\mathrm{lH}$ to $-24 \mathrm{H}$ ) from Hole 769B. Each vertical bar has a width of the corresponding core depth interval and a length of two $\alpha 95$. The horizontal line shows the dipole-predicted inclination $\left(17.2^{\circ}\right)$ for Site 769 . 


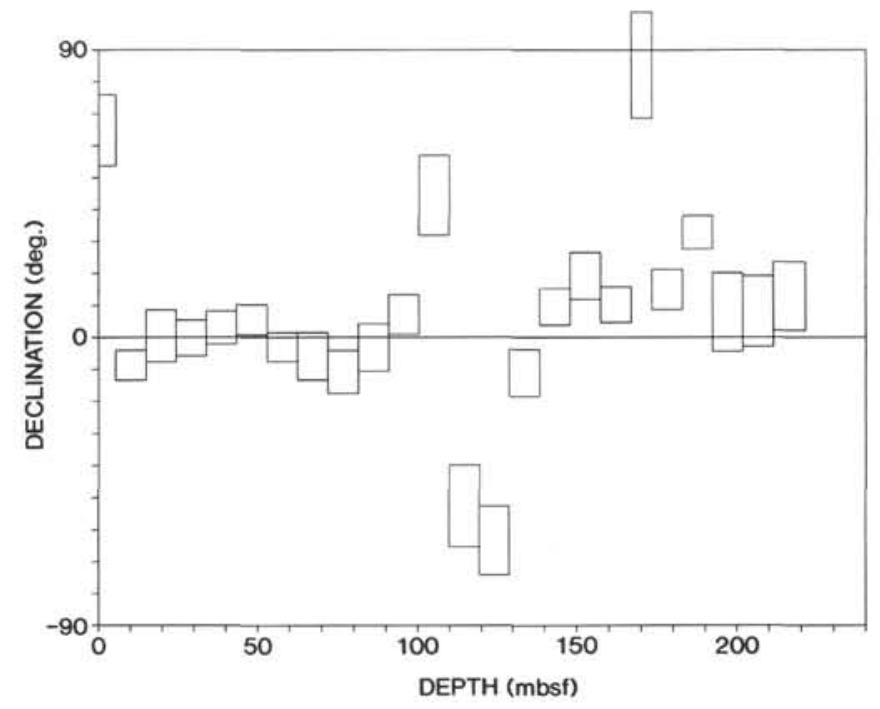

Figure 10. Average declinations of the APC cores from Hole 769B. Each vertical bar has a width of the corresponding core depth interval and a length of two $\alpha 95$.
Table 1. Averaged directions (declination and inclination) of all APC cores from Hole 769B.

\begin{tabular}{rrrrrrr}
\hline Core & N & Dec. & Inc. & R & K & d95 \\
\hline 1 & 3 & 64.80 & 13.38 & 2.98 & 124.89 & 11.08 \\
2 & 19 & -8.70 & 7.37 & 18.65 & 51.81 & 4.71 \\
3 & 10 & .44 & 10.05 & 9.75 & 36.26 & 8.13 \\
4 & 14 & -.22 & 7.99 & 13.75 & 51.54 & 5.59 \\
5 & 14 & 3.12 & 11.27 & 13.78 & 60.16 & 5.17 \\
6 & 18 & 5.51 & 9.07 & 17.68 & 53.84 & 4.75 \\
7 & 15 & -3.09 & 7.98 & 14.81 & 73.33 & 4.50 \\
8 & 12 & -5.96 & 12.60 & 11.68 & 34.78 & 7.46 \\
9 & 10 & -10.83 & 17.86 & 9.83 & 52.85 & 6.71 \\
10 & 5 & -3.28 & 14.85 & 4.96 & 106.86 & 7.44 \\
11 & 11 & 7.15 & 5.59 & 10.82 & 56.08 & 6.15 \\
12 & 7 & 44.47 & 9.86 & 6.75 & 23.93 & 12.59 \\
13 & 3 & -52.68 & 10.10 & 2.98 & 94.89 & 12.73 \\
14 & 4 & -63.39 & 4.38 & 3.96 & 74.05 & 10.75 \\
15 & 14 & -11.14 & 9.95 & 13.56 & 29.81 & 7.40 \\
16 & 18 & 9.58 & 2.45 & 17.55 & 37.90 & 5.69 \\
17 & 17 & 19.28 & -.67 & 16.36 & 24.86 & 7.30 \\
18 & 17 & 10.23 & 2.44 & 16.63 & 42.84 & 5.51 \\
19 & 8 & 85.16 & -4.50 & 7.42 & 12.17 & 16.54 \\
20 & 18 & 14.94 & -3.93 & 17.47 & 31.94 & 6.21 \\
21 & 17 & 32.81 & .87 & 16.66 & 47.37 & 5.24 \\
22 & 12 & 7.91 & -6.25 & 11.18 & 13.49 & 12.27 \\
23 & 15 & 8.17 & -12.75 & 13.92 & 12.94 & 11.05 \\
24 & 11 & 12.87 & -4.72 & 10.48 & 19.20 & 10.69 \\
\hline
\end{tabular}

$\mathrm{N}$ is number of samples averaged; $\mathrm{R}$ is the length of vector sum of $\mathrm{N}$ unit vectors; $\mathrm{K}$ is the precision parameter; $\alpha 95$ is the radius of the $95 \%$ confidence cone.

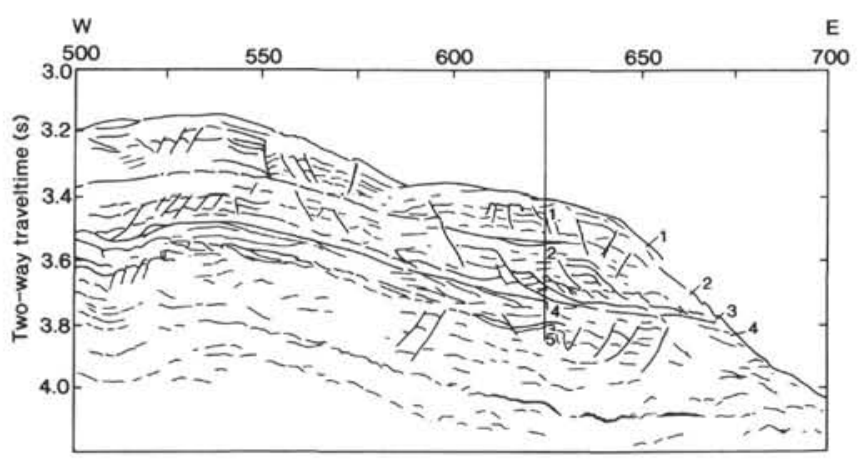

Figure 11. A line-drawing interpretation of a multichannel seismic reflection line crossing Site SS5, which is close to Site 769. Figure is adopted from Rangin, Silver, von Breymann et al., (1990). Seismic sequences $1,2,3$, and 4 are equivalent to lithology units I, IIA, IIB, and III of Figures 4 and 7. 